\title{
Structure of the testate amoebae community in different habitats in a neotropical floodplain
}

\author{
Lansac-Tôha, FA. ${ }^{a *}$, Velho, LFM. ${ }^{a}$, Costa, DM. ${ }^{a}$, Simões, NR. ${ }^{a}$ and Alves, GM. ${ }^{b}$ \\ aPostgraduate Course in Ecology of Continental Aquatic Environments - PEA, Universidade Estadual de Maringá - UEM, \\ Av. Colombo, 5790, CEP 87020-900, Maringá, PR, Brazil \\ Faculdade Maringá - Uningá, Rodovia PR 317, 6114, CEP 87035-510, Maringá, PR, Brazil \\ *e-mail: fabio@nupelia.uem.br
}

Received: November 26, 2012 - Accepted: January 23, 2013 - Distributed: February 28, 2014

(With 4 figures and 2 plates)

\begin{abstract}
This study evaluated the differences in composition, abundance and morphology of testate amoebae among different habitats of the same aquatic environment (plankton, aquatic macrophyte and sediment) in the Upper Paraná River floodplain. Triplicate samplings were undertaken monthly at each habitat from April 2007 to March 2008. The structure of the community of testate amoebae was different among the habitats. The species typical for each habitat, according to Indval, were classified by their shell morphology. Arcella species together with Difflugia gramen and Difflugia pseudogramem were more abundant for plankton. Trinema and Phryganella stood out by their abundance and frequency in aquatic macrophytes. Centropyxis was an indicator of sediment. The results indicated a higher frequency of hemispherical and spherical shells in plankton and spherical and elongated shells in aquatic macrophytes. In the sediment, there was a high frequency of elongated species. Our results support the hypothesis that the community of testate amoebae has different structures among the habitats, refuting the idea that the organization of this community in plankton is guided by random events like the resuspension of organisms from the sediment and their displacement from marginal vegetation.
\end{abstract}

Keywords: protists, floodplain lake, aquatic macrophytes, plankton, sediment.

\section{Estrutura da comunidade de amebas testáceas em diferentes hábitats em uma planície de inundação neotropical}

\section{Resumo}

Este estudo avaliou as diferenças na composição, abundância e morfologia das amebas testáceas entre diferentes hábitats de um mesmo ambiente aquático (plâncton, macrófitas aquáticas e sedimento) da planície de inundação do alto rio Paraná. As amostras foram coletadas mensalmente no período de abril de 2007 a março de 2008. A estrutura da comunidade de amebas testáceas foi diferente entre os hábitats. As espécies típicas para cada hábitat, de acordo com o Indval, foram classificadas pela morfologia da teca. Espécies de Arcella, Difflugia gramen e Difflugia pseudogramem foram mais abundantes para o plâncton. Trinema e Phryganella destacaram-se pela alta abundância e frequência nas macrófitas aquáticas. Centropyxis foi considerado indicador do sedimento. Os resultados indicaram uma alta frequência de tecas esféricas e hemisféricas no plâncton e de tecas alongadas nas macrófitas aquáticas. No sedimento foi registrada uma maior frequência de espécies alongadas. Nossos resultados suportam a hipótese que a comunidade de amebas testáceas possui estrutura diferente entre os hábitats, refutando a ideia que a comunidade presente no plâncton é guiada por processos estocásticos como a ressuspensão dos organismos do sedimento e simples carreamento da vegetação marginal.

Palavras-chave: protistas, planície de inundação, macrófitas aquáticas, plâncton, sedimento.

\section{Introduction}

Testate amoebae are protists whose protoplasm is inserted into a test (shell) with an oral aperture through which the pseudopods emerge during locomotion or feeding (Smith et al., 2008). These protists are present in a wide variety of habitats, such as lakes, lagoons, rivers, wet soils, mosses, bogs (Mattheeussen et al., 2005), estuarine environments (Ferreira et al., 2006) and in the marine supralittoral sand (Golemansky and Todorov, 2004).

In inland aquatic environments, testate amoebae have been studied in different habitats like sediment, 
aquatic macrophytes and plankton of rivers, reservoirs and lakes (Balik and Song, 2000; Velho et al., 2004; LansacTôha et al., 2007, 2008; Todorov et al., 2008; Snegovaya and Alekperov, 2009). However, there are few studies that concomitantly evaluate the community structure of these protists in these three habitats within the same environment (Alves et al., 2010, 2012).

Among the above cited habitats, in Brazil, the lacustrine sediment is the least surveyed, since most studies performed with samples from this habitat have been conducted in coastal lagoons or estuaries, where the salinity is a limiting factor for the occurrence of these organisms (LansacTôha et al., 2007).

Regarding the community associated with aquatic macrophytes, the occurrence and abundance of testate amoebae in this habitat are closely linked to a set of factors provided by these plants, such as the microenvironments within the water column (Declerck et al., 2007), reduction of physical disturbances in the system (Cardinale et al., 1998) and increase in structural complexity (Thomaz et al., 2008), which consequently increase the abundance and diversity of the food supply (periphyton productivity).

Although testate amoebae are not considered by numerous authors as typically planktonic, in Brazil, the highest diversity of these protists have been recorded in plankton, when compared to macrophytes and lacustrine sediment (Lansac-Tôha et al., 2007, 2009), especially in environments from the Upper Paraná River floodplain (Velho et al., 2004; Alves et al., 2007, 2008; LansacTôha et al., 2007, 2008). In this ecosystem, various habitats have been sampled, including marginal lakes and small channels and tributaries, as well as the main river. The lakes are mostly shallow and have a great development of marginal vegetation. The pelagic and littoral regions are in close proximity, and there is also a daily mixture of the water column, which can intensify the exchange of organisms among the different habitats (Lansac-Tôha et al., 2003). In this sense, some authors have stated that although testate amoebae have no preference for plankton as their preferential habitat, they are frequently found in samples of this habitat and the occurrence of some individuals in plankton cannot be only occasional as a result of the displacement of these organisms from the sediment and marginal vegetation (Green, 1994; Velho et al., 2003; Lansac-Tôha et al., 2004; Alves et al., 2010).

Thus, in addition to studies of Alves et al. (2010, 2012) that evaluated, respectively, two components of species diversity (alpha and gamma) and the relationship between the size structure of testate amoebae in distinct habitats (plankton, aquatic macrophytes and sediment) of a marginal lake in the Upper Paraná River floodplain, this study aimed to evaluate the differences in composition, abundance and morphology of testate amoebae among the populations present in these same habitats. For this, if the presence of testate amoebae in plankton is only due to occasional processes, then the following predictions are true: i. The structure of the testate amoeba community recorded in plankton will be similar to that present in aquatic macrophytes and sediment;

ii. The similarity of the amoebae among the habitats will be higher during the high water period, since the displacement of these organisms from marginal vegetation (aquatic macrophytes) and sediment is greater in this period;

iii. The predominant morphological type of the shells in the plankton will be the same as that identified for the preferred habitats.

\section{Materials and Methods}

\subsection{Study area}

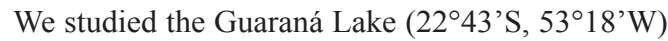
connected to the Baía River through a channel 70-m long and 18-m wide (Figure 1). The Guaraná Lake presents a rounded shape with a mean depth of $2.1 \mathrm{~m}$, a perimeter of $1,058.3 \mathrm{~m}$, and an area of 4.2 ha (Teixeira et al., 2008). This lake, belonging to the Upper Paraná River floodplain present dark-brown water, sandy sediment rich in decaying organic matter and the edges with grasses and bushes.

\subsection{Field sampling}

Triplicate sampling was conducted monthly from April 2007 to March 2008 at each habitat: plankton, aquatic macrophytes and aquatic sediment. At each sampling point, we measured the $\mathrm{pH}$, temperature $\left({ }^{\circ} \mathrm{C}\right)$, dissolved oxygen $(\mathrm{mg} / \mathrm{L})$ and conductivity $(\mathrm{mS} / \mathrm{cm})$ using digital portable potentiometers. However, these data were similar among the habitats throughout the study period and the differences observed in the structure of the community of the testate amoebae should not be ascribed to limnological variables (Alves et al., 2012).

\subsubsection{Plankton}

We filtered $50 \mathrm{~L}$ of water per sample through a plankton net $(20 \mathrm{~mm})$. Plankton samples were taken at the subsurface of the pelagic region using a Van Dorn bottle (5 L). Samples were preserved with formaldehyde solution (4\%) buffered with calcium carbonate.

\subsubsection{Aquatic macrophytes}

Sampling was carried out using a net $(20 \mathrm{~mm})$ with an opening $30 \mathrm{~cm}$ in diameter (area $=706 \mathrm{~cm}^{2}$ ), which was placed under multispecific aquatic macrophyte stands. All plants within this area were sampled and kept in plastic bags, along with all the material retained in the net. The testate amoebae associated with the macrophytes were removed by washing the vegetation in two buckets: the first bucket had $3 \mathrm{~L}$ of formaldehyde solution (4\%) buffered with calcium carbonate and the second bucket had $3 \mathrm{~L}$ of water. The retained materials from the two buckets were filtered through a net $(20 \mathrm{~mm})$ and preserved in formaldehyde solution (4\%) buffered with calcium carbonate. 


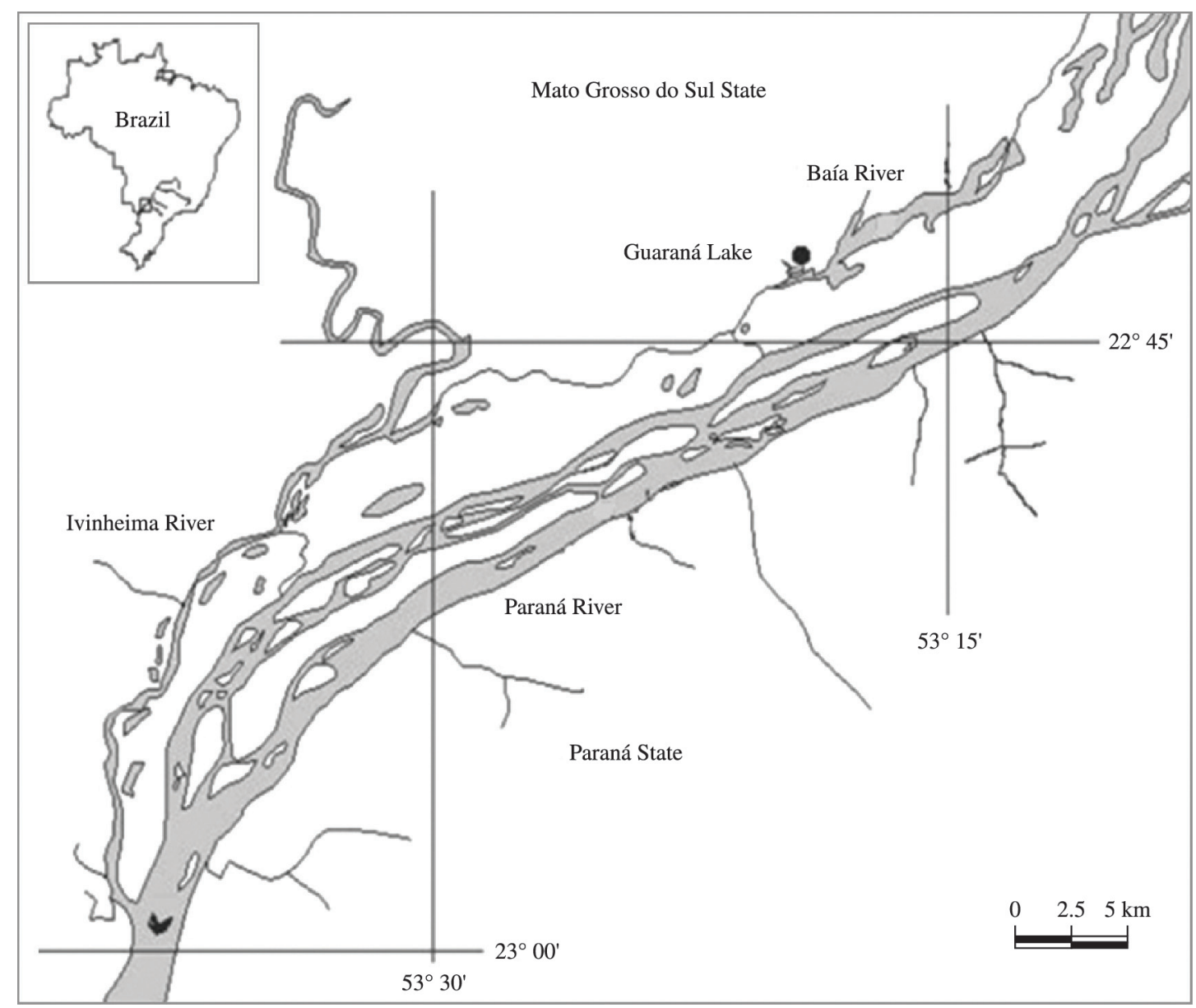

Figure 1. Map of study area with location of the sampling station.

During the study period, we sampled free-floating aquatic macrophytes (Eichhornia crassipes (Mart.) Solms, Salvinia auriculata Aubl., Salvinia biloba Raddi, Pistia stratiotes L., Limnobium laevigatum (Humb. and Bonpl. ex Willd.) Heine, Wolffiella sp.), emergent macrophytes (Eichhornia azurea (Sw.) Kunth, Hidrocotyle ranunculoides L. f., Paspalum repens P.J. Bergius, Ludwigia sp.) and a rooted floating- leaved macrophyte (Nymphaea amazonum Mart. and Zucc.) in the littoral region of Guaraná Lake. Only the last four species were not present during all sampling.

\subsubsection{Aquatic sediment}

Testate amoebae were sampled in the sediment from the central region of the lake using an Ekman bottom grab sampler. From the collected material, an area of $100 \mathrm{~cm}^{2}$ was removed for analysis and only the superior layer of the sediment (the first centimeter) was sampled. The material was kept in polyethylene flasks containing formaldehyde solution (4\%) buffered with calcium carbonate.

\subsection{Laboratory analysis}

The samples were stained with Rose Bengal and only organisms with stained protoplasm (indicating that they were alive at the time of the sampling) were counted and identified. Subsamples were obtained using a HensenStempell pipette $(2.5 \mathrm{ml})$ and analyzed in a Sedgwick-Rafter chamber. The individuals were sorted from each sample and mounted on glycerin slides for later identification. The analyses were made using an optical microscope (Olympus).

The taxonomic classification was based on Adl et al. (2005). Thus, our species were grouped into two taxonomic categories: Arcellinida Kent, 1880 (Amoebozoa, Testacealobosia) and Euglyphida Copeland, 1956 (Rhizaria, Silicofilosea). The identification was performed using the following bibliography: Deflandre (1928, 1929), GauthierLièvre and Thomas (1958, 1960), Vucetich (1973), Ogden and Hedley (1980), Velho and Lansac-Tôha (1996), Velho et al. (1996), Alves et al. (2007) and Souza (2008).

\subsection{Data analysis}

In this period, the depth of the lake ranged from 1.4 to $2.5 \mathrm{~m}$. December 2007, and January and February 2008 with deeper water, were considered as the high water period and May, June and July 2007 with shallower water, were considered as the low water period (Alves et al., 2012). 
The density of testate amoebae recorded in plankton was estimated in ind . $\mathrm{m}^{-3}$, while in aquatic macrophyte and in sediment, in ind. $\mathrm{m}^{-2}$. Due to the wide range of these values, the final density of the different habitats was expressed as $\log (\mathrm{x}+1)$.

The similarity between the community structures in the different habitats was represented by the non-metric multidimensional scaling (NMDS) using Bray-Curtis dissimilarity (Clarke and Warwick, 1994). We used the Permutational Multivariate Analysis of Variance (PERMANOVA) (Anderson, 2001) to evaluate the effects of the habitats (plankton, aquatic macrophytes and sediment) and sampling periods (high water and low water) on testate amoebae. This is a multi-factorial ANOVA suitable for analyzing multivariate data that are based on any distance measure. Permutation methods are used to measure the significance level of the statistical criterion (Anderson, 2001).

We also calculated the indicator value of species IndVal (Dufrêne and Legendre, 1997) with a significance level of $5 \%$ to verify the species typical of each habitat. Afterwards, we checked the possible relationship between the morphological types of the shells with the analyzed habitat. The classification of the morphological types was based on that of Velho et al. (2003), which included four types: elongated, flattened, spherical and hemispherical.

The NMDS and PERMANOVA analyses used data of relative density of the distinct habitats, aiming to minimize the differences between the sampling efforts employed. To conduct these analyses, rare taxa were excluded (frequency $<10 \%$ of samples).

The analyses were run on software R. PERMANOVA analysis was carried out using the function "adonis" from the vegan package (Oksanen et al., 2010), also using software R (R Development Core Team, 2011), and a Monte Carlo method with 10,000 random permutations to assess significance levels.

\section{Results}

In this period, were identified 89 infrageneric taxa, belonging to 10 families, with Difflugiidae (41 taxa), Arcellidae (18 taxa), Centropyxidae (11 taxa) and Lesquereusiidae (10 taxa) being the most representative regarding the number of taxa (Alves et al., 2010, 2012). When assessing the distribution of the mean density of testate amoebae in the different habitats, no pattern of temporal distribution was verified. Hence, no similar trends of an increase or decrease were detected in the number of individuals among the populations present in plankton, aquatic macrophytes and sediment in this period (Figure 2).

The non-metric multidimensional scaling (NMDS) demonstrated distinct patterns of composition and relative abundance of testate amoebae among the sampled habitats, with a greater similarity between the communities in the sediment and aquatic macrophytes, as shown by the proximity of the points referring to these habitats (Figure 3). PERMANOVA indicated significant differences $(\mathrm{F}=18.45$

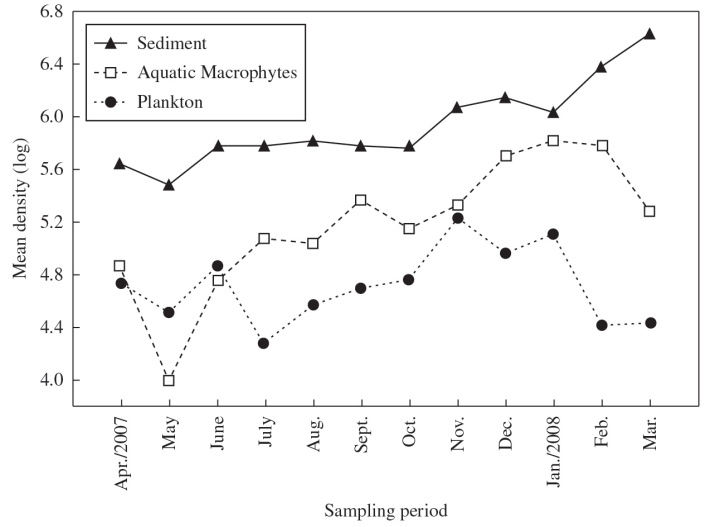

Figure 2. Temporal fluctuation of the mean density of testate amoebae in different studied habitats (plankton $=\log$ ind. $\mathrm{m}^{-3}$; macrophyte and sediment $=\log$ ind $\left.\cdot \mathrm{m}^{-2}\right)$.

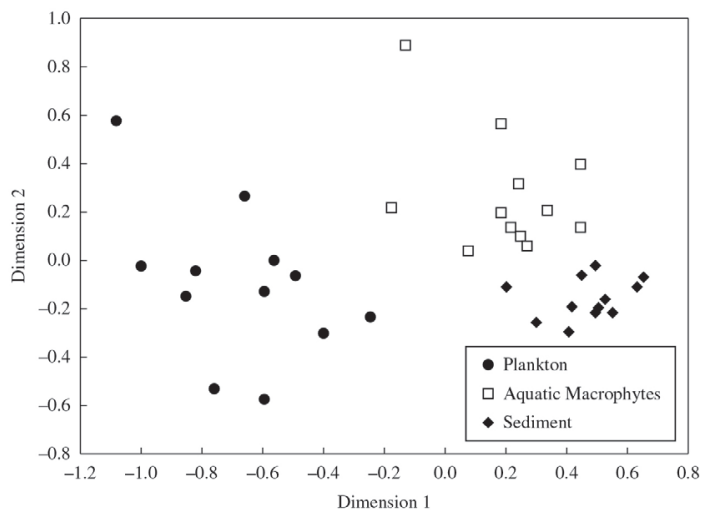

Figure 3. Non-metric multidimensional scaling (NMDS) of the structure of testate amoebae community of the different habitats sampled during the period from April 2007 to March 2008 (stress $=0.11$ ).

Table 1. PERMANOVA results. D.f. $=$ degrees of freedom; $p=$ significance based on 10,000 randomizations. Bold letters indicate significant $p$-values.

\begin{tabular}{cccc}
\hline Factors & D.f. & F & P \\
\hline Period & 1 & 3.50 & 0.02 \\
Habitat & 2 & 18.80 & 0.01 \\
Period*Habitat & 2 & 1.91 & 0.09 \\
\hline
\end{tabular}

and $p<0.01)$ in the community structure of these protozoans among the examined habitats.

There was no influence of the hydrological period on the studied habitats (no significant interaction), but significant differences were observed among habitats and the hydrological periods, separately (Table 1).

The indicator value of species (IndVal) $(p<0.05)$ selected 39 indicator species: six for plankton, 14 for the aquatic macrophytes and 19 for the sediment (Table 2).

By classifying the species typical for each habitat according to Indval and shell morphology, the results indicated a greater frequency of hemispherical and spherical 
Table 2. Indicator species for each habitat obtained by analyzing Indval.

\begin{tabular}{|c|c|}
\hline Plankton & $\begin{array}{r}\text { Aquatic Macrophytes } \\
\end{array}$ \\
\hline Arcella conica (Playfair, 1917) & Arcella discoides Ehrenberg, 1843 \\
\hline A. gibbosa Pénard, 1890 & A. rotundata var. aplanata Deflandre, 1928 \\
\hline A. gibbosa var. mitriformis Deflandre, 1928 & Centropyxis aculeata (Ehrenberg, 1838) \\
\hline A. hemisphaerica Perty, 1852 & Difflugia corona f. tuberculata Vucetich, 1973 \\
\hline Difflugia gramen Pénard, 1902 & D. elegans Pénard, 1890 \\
\hline \multirow[t]{9}{*}{ D. pseudogramen G-L \& Th, 1960} & D. lobostoma var. cornuta G-L \& Th, 1958 \\
\hline & D. lobostoma var. multilobata G-L \& Th, 1958 \\
\hline & D. pleustonica Dioni, 1970 \\
\hline & D. schuurmanni Van Oye, 1932 \\
\hline & Euglypha acanthophora (Ehrenberg, 1841) \\
\hline & Lesquereusia modesta Rhumbler, 1896 \\
\hline & Netzelia oviformis (Cash, 1909) \\
\hline & Phryganella sp. \\
\hline & Trinema sp. \\
\hline
\end{tabular}

\section{Sediment}

Centropyxis aerophila var. sphanicola Deflandre, 1929

C.constricta (Ehrenberg, 1841)

C.discoides (Pénard, 1890)

C.ecornis (Ehrenberg, 1841)

C.marsupiformis (Wallich, 1864)

C.platystoma (Pénard, 1902)

Cyclopyxis kahli (Deflandre, 1929)

Difflugia acuminata Ehrenberg, 1838

D.acutissima Deflandre, 1931

D. cf. parva (Thomas, 1954)

D.microclaviformis (Kourov, 1925)

D.muriformis G-L \& Th, 1958

D.oblonga Ehrenberg, 1838

D.ventricosa f. recticaulis Dioni, 1970

Hoogenraadia cryptostoma G-L \& Th, 1958

Lesquereusia modesta v. caudata (Playfair, 1917)

L. spiralis (Ehrenberg, 1840)

Netzelia tuberculata (Wallich, 1864)

Plagyopyxis callida Pénard, 1910

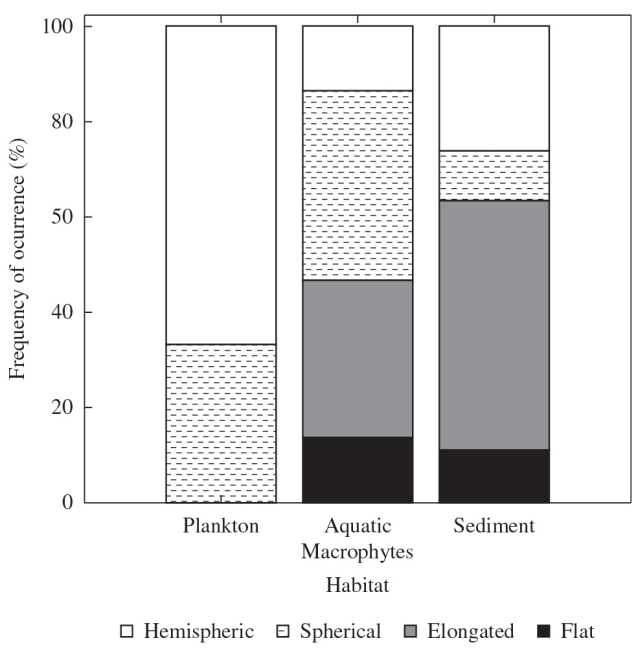

Figure 4. Frequency of occurrence of the morphological shell types in the different habitats. shells in the amoeba community in plankton, and spherical and elongated shells in aquatic macrophytes. In the sediment, there was a high frequency of elongated species (Figure 4). Some of the indicator species for each habitat and their respective shell morfology are represented in two plates. The Plate I shows indicator species of plankton and aquatic macrophytes. The Plate II presents indicator species of the sediment. The illustrations presented in the plates were adapted from Alves et al. (2007) and LansacTôha et al. (2008).

\section{Discussion}

This study showed differences in the occurrence and relative density of testate amoebae among the habitats and between the hydrological periods without a significant interaction (NMDS and PERMANOVA), as well as in distribution pattern of the density of testate amoebae in the different habitats. Thus, the structure of the community of 


\section{PLANKTON}
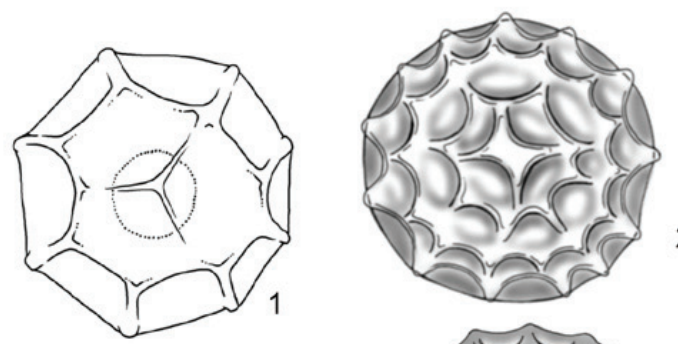

2
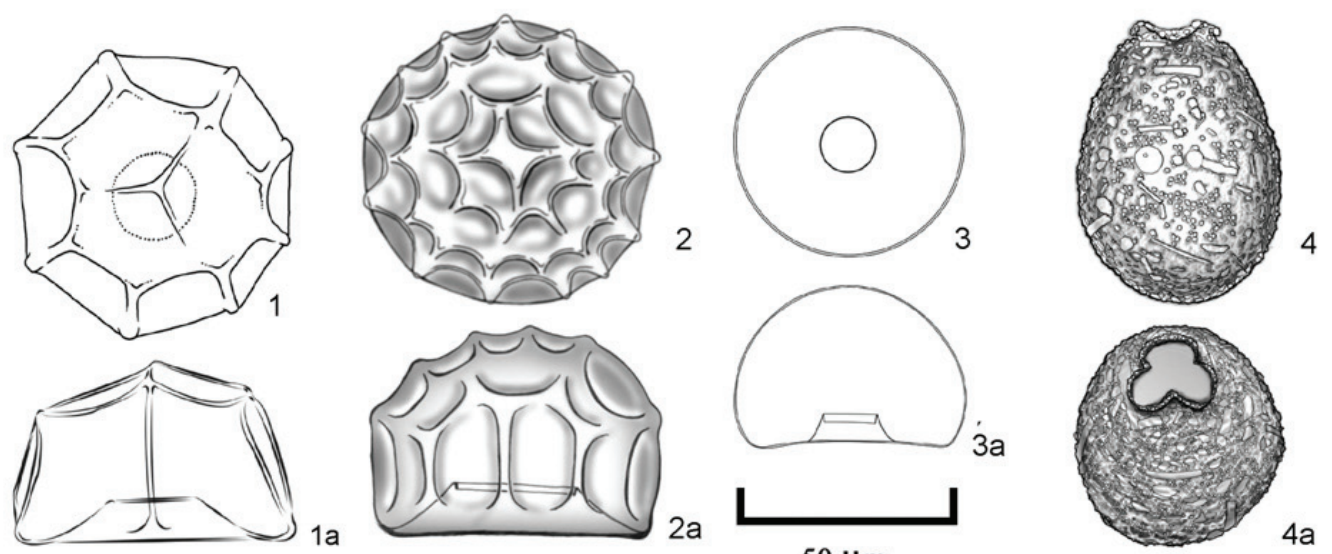

\section{AQUATIC MACROPHYTES}
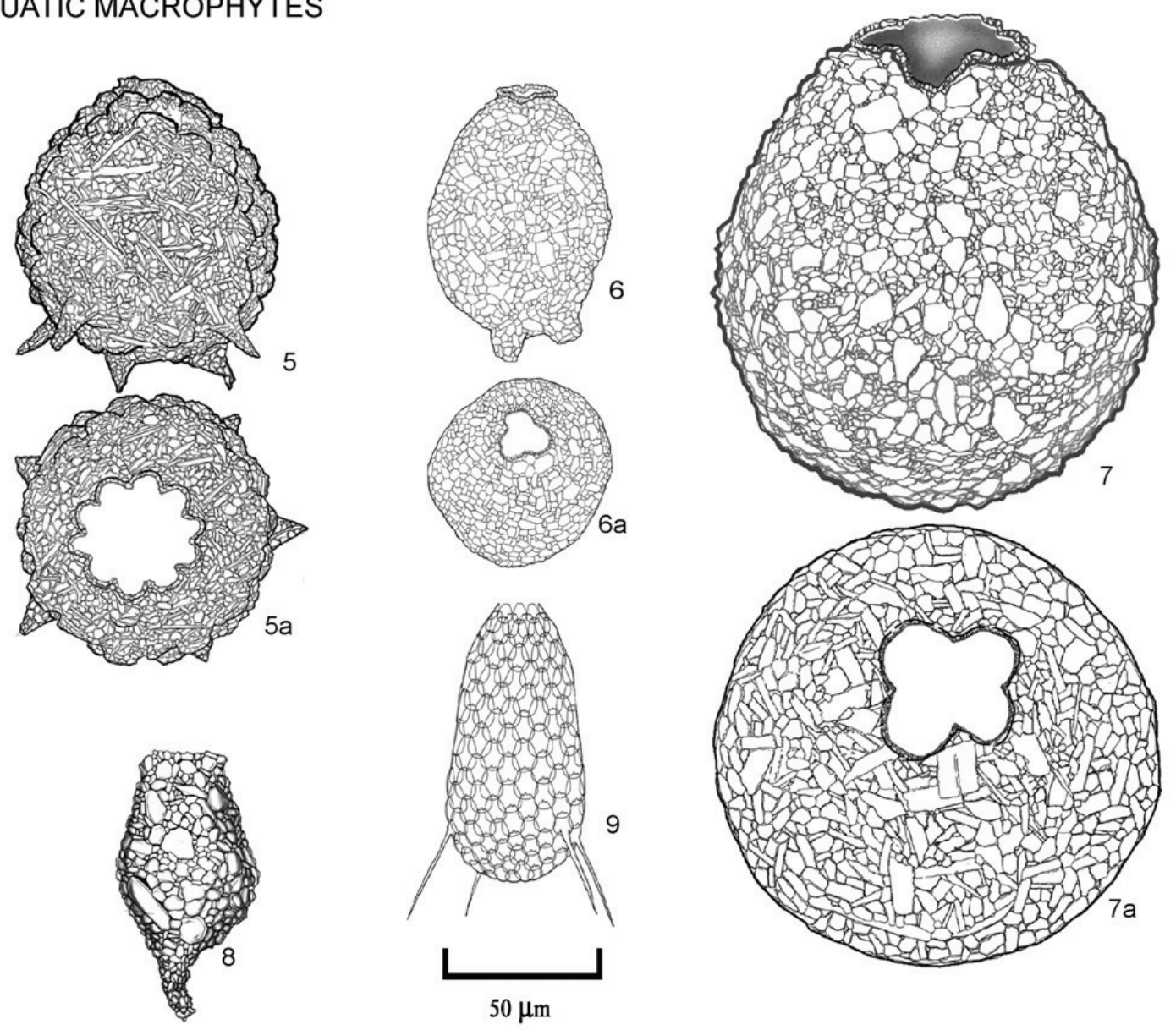

Plate I. PLANKTON: Hemispheric shells - Fig. 1. Arcella conica, apical view; Fig. 1a. lateral view; Fig. 2. A. gibbosa var. mitriformis, apical view; Fig. 2a. lateral view; Fig. 3. A. hemisphaerica, ventral view; Fig. 3a. lateral view; Spherical shell Fig. 4. Difflugia pseudogramen, lateral view; Fig. 4a. apical view. AQUATIC MACROPHYTES: Spherical shells - Fig. 5. Difflugia corona f. tuberculata, lateral view; Fig. 5a. apical view; Fig. 6. D. lobostoma var. cornuta, lateral view; Fig. 6 a. apical view; Fig. 7. Netzelia oviformis, lateral view; Fig. 7a. apical view; Elongated shells - Fig. 8. Difflugia elegans, lateral view; Fig. 9. Euglypha acanthophora, lateral view. 

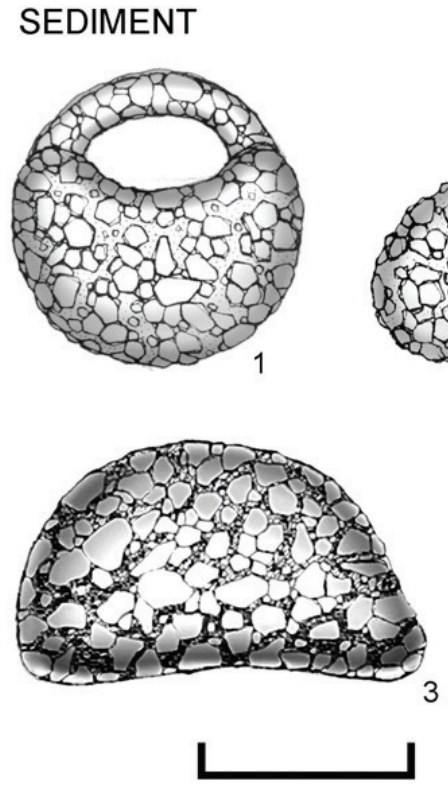

$50 \mu \mathrm{m}$

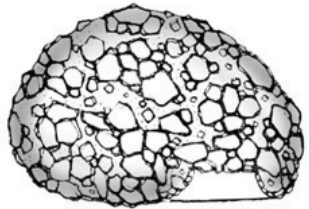

$1 \mathrm{a}$
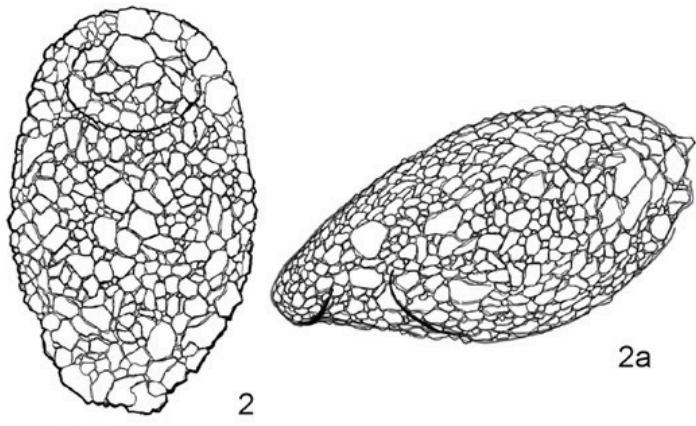

$2 a$

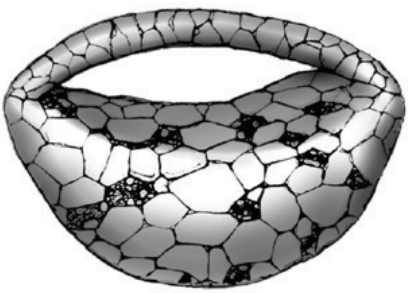

$3 b$

3a
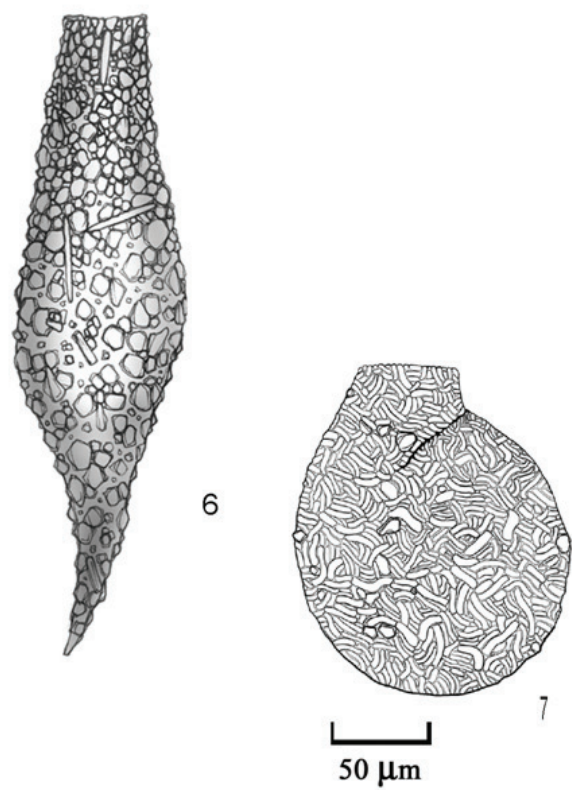

Plate II. SEDIMENT: Hemispheric shells - Fig. 1. Centropyxis aerophila var. sphagnicola, ventral view; Fig. 1a. lateral view; Fig. 2. C. constricta, ventral view; Fig. 2a. lateral view; Fig. 3. Plagiopyxis callida, lateral view; Fig. 3a. ventral view; Fig. 3b. pseudostome. Elongated shells - Fig. 4. Difflugia microclaviformis, lateral view; Fig. 5. D. acutissima, lateral view; Fig. 6. D. ventricosa f. recticaulis, lateral view; Fig. 7. Lesquereusia spiralis, lateral view. 
testate amoebae is different among the habitats regardless of the hydrological period, suggesting an organization of the community over time. Given that the flood pulse is one of the driving factors in community structuring in wetland environments, if the presence of testate amoebae in plankton is only explained by occasional processes, the rising water level in the high water period will therefore homogenize the composition and abundance of testate amoebae in the different habitats sampled.

Differences in the predominant families in each habitat were observed. In studies with plankton communities, Arcellidae is one of the predominant families, along with Difflugiidae and Centropyxidae (Velho et al., 2004; Lansac-Tôha et al., 2007, 2008; Alves et al., 2008). On the other hand, in samples from macrophytes and sediments, Lesquereusiidae stands out among the most predominant families (Dabés and Velho, 2001; Leipnitz et al., 2006; Lansac-Tôha et al., 2007; Leão et al., 2009).

Some species were typical of the studied habitats, probably due to adaptations that ensure their success at each habitat. Arcella (Arcellidae) was most representative in plankton. This genus is quite common and abundant in samples from this habitat (Velho et al., 1996; LansacTôha et al., 2000). The shells of this genus are usually small, of low density and composed of endogenous material secreted by the amoeba itself, which allows greater ease of occupation of the plankton habitat. The reduced presence of Arcella in sediment samples is similar to that seen in other studies performed in this habitat, suggesting the low ability to preserve the shells of this genus in these environments (Leipnitz et al., 2006).

Furthermore, Difflugia gramen and D. pseudogramen, highlighted by their occurrence and abundance in plankton, have the same type of morphology, i.e., spherical shells. This morphological type, together with the type of Arcella shells (hemispherical), was typical of the plankton habitat. The same pattern of shapes recorded in the community in plankton (hemispherical and spherical) was verified by Velho et al. (2003) as typical of this same habitat in lentic environments. However, these authors also identified elongated and flattened shapes, which in this study have been observed in macrophytes and sediment, as typical of littoral region of lentic environments, as well as of plankton from lotic environments. These authors studied the influence of environmental heterogeneity on the structure of the testate amoeba community by analyzing samples from the pelagic and littoral region of different lotic and lentic environments of the Upper Paraná River floodplain.

In this way, there is probably a singularity in the morphology of testate amoebae in plankton of lentic environments, with a predominance of spherical and hemispherical shapes, since they can adapt easily to the limnetic region of the lakes, where the need for resisting flow is lower. Besides that, the gas vacuoles for floating (Bles, 1929; Štěpánek and Jiří, 1958) and low density shells (Schönborn, 1962), as observed in the community in plankton of Lake Guaraná, allow the persistence of these protists in this habitat.
Trinema and Phryganella stood out by their abundance and frequency in aquatic macrophytes. Trinema has shells formed by juxtaposed platelets, which are sensitive and translucent. The shells of the genus Phryganella are fragile and can be easily broken, due to the wide pseudostomal aperture (Souza, 2008). Thus, the structural complexity of the aquatic macrophytes provides greater protection and availability of microhabitats to these genera.

Centropyxis was an indicator of sediment (6 taxa), except for C. aculeata, as observed in macrophytes. This genus has a shell mostly formed by exogenous material, like sand grains and diatom frustules that are more available at the bottom of the lake. C. constricta was frequent in a study of surface sediments from the bottom of streams and lakes of the National Park of 'Lagoa do Peixe' (Mato Grosso do Sul State) (Leipnitz et al., 2006).

In summary, plankton had a peculiarity in the composition of the testate amoeba community, which was opposite to that predicted by stochasticity, in which there would be a similarity in the composition among the different habitats, especially during the high water period. Moreover, the types elongated and flattened of shells were specific in preferential habitats, but not seen in the community in plankton.

The proposed predictions that could explain the occasional presence of testate amoebae in the plankton of a lentic environment governed by random events, such as the resuspension of these organisms from sediment and displacement from aquatic macrophytes in the marginal region, were rejected. Therefore, our results suggest that the singular traits of each habitat (plankton, aquatic macrophytes and sediment) are reflected in the development of populations with different characteristics in relation to the composition and morphology of the shell.

Acknowledgments - We thank to CNPq/Peld and Nupélia/ PEA/UEM by the financial and logistic support.

\section{References}

ADL, SM., SIMPSON, AGB., FARMER, MA., ANDERSEN, RA., ANDERSON, OR., BARTA, JR., BOWSER, SS., BRUGEROLLE, G., FENSOME, RA., FREDERICQ, S., JAMES, TY., KARPOV, S., KUGRENS, P., KRUG, J., LANE, CE., LEWIS, LA., LODGE, J., LYNN, DH., MANN, DG., MCCOURT, RM., MENDOZA, L., MOESTRUP, O., MOZLEY-STANDRIDGE, SE., NERAD, TA., SHEARER, CA., SMIRNOV, AV., SPIEGEL, FW. and TAYLOR, MFJR., 2005. The new higher level classification of eukaryotes with emphasis on the taxonomy of Protists. Journal of Eukaryotic Microbiology, vol. 52, p. 399-451. PMid:16248873. http://dx.doi.org/10.1111/j.1550-7408.2005.00053.x

ALVES, GM., LANSAC-TÔHA, FA., TAKAHAHI, EM. and VELHO, LFM., 2008. Fluctuations of testate amoebae populations (Rhizopoda) in plankton from different environments on the upper Paraná River floodplain, Brazil. International Review of Hydrobiology, vol. 93, p. 227-242. http://dx.doi.org/10.1002/ iroh.200711002

ALVES, GM., VELHO, LFM., SIMÕES, NR. and LANSACTÔHA, FA., 2010. Biodiversity of testate amoebae (Arcellinida and Euglyphida) in different habitats of a lake in the upper 
Paraná River floodplain. European Journal of Protistology, vol. 46, p. 310-318. PMid:20869856. http://dx.doi.org/10.1016/j. ejop.2010.07.001

ALVES, GM., VELHO, LFM., COSTA, DM. and LANSACTÔHA, FA., 2012. Size structure of testate amoebae (Arcellinida and Euglyphida) in different habitats from a lake in the upper Paraná River floodplain. European Journal of Protistology, vol. 48, p. 169-177. PMid:22261279. http://dx.doi.org/10.1016/j. ejop.2011.10.004

ALVES, GM., LANSAC-TÔHA, FA., VELHO, LFM., JOKO, CY. and COSTA, DM., 2007. New records of testate amoebae (Protozoa: Testacealobosea) for Upper Paraná River floodplain. Acta Limnologica Brasiliensia, vol. 19, p. 175-195.

ANDERSON, MJ., 2001. A new method for non-parametric multivariate analysis of variance. Austral Ecology, vol. 26, p. 32-46.

BALIK, V. and SONG, B., 2000. Benthic freshwater testate amoebae assemblages (Protozoa: Rhizopoda) from Lake Dongting, People's Republic of China, with description of a new species from the genus Collaripyxidia. Acta Protozoologica, vol. 39, p. 149-156.

BLES, EJ., 1929. Arcella. A Study in Cell Physiology. Quarterly Journal of Microscopical Science, vol. 72, p. 527-648.

CARDINALE, BJ., BRADY, VJ. and BURTON, TM., 1998. Changes in the abundance and diversity of coastal wetland fauna from the open water/macrophyte edge towards the shore. Wetlands Ecology and Management, vol. 6, p. 50-68.

CLARKE, KR. and WARWICK, RM., 1994. Change in Marine Communities: An Approach to Statistical Analysis and Interpretation. Plymouth: Natural Environment Research Council. 144 p.

DABÉS, M.B.G.S. and VELHO, L.F.M., 2001. Testate amoebae (Protozoa, Rhizopoda) associated to littoral aquatic macrophytes in a marginal lake of the São Francisco River, MG, Brazil. Acta Scientiarum, vol. 23, p. 299-304.

DECLERCK, S., VANDERSTUKKEN, M., PALS, A, MUYLAERT, K. and DE MEESTER, L., 2007. Plankton biodiversity along a gradient of productivity and its mediation by macrophytes. Ecology, vol. 88, p. 2199-2210. PMid:17918398. http://dx.doi. org/10.1890/07-0048.1

DEFLANDRE, G., 1928. Le genre Arcella Ehrenberg. Archiv für Protistenkunde, vol. 64, p. 152-287.

-, 1929. Le genre Centropyxis Stein. Archiv für Protistenkunde, vol. 67, p. 322-375.

DUFRÊNE, M. and LEGENDRE, P., 1997. Species assemblages and indicator species: the need for a flexible asymmetrical approach. Ecological Monographs, vol. 67, p. 345-366.

FERREIRA, F., LEIPNITIZ, I., LEÃO, CJ. and HANSEN, MAF., 2006. Tecamebas em sedimentos do rio Tramandaí e da lagoa do Passo, planície costeira norte do Estado do Rio Grande do Sul, Brasil. GAEA, vol. 2, p. 66-74.

GAUTHIER-LIÈVRE, L. and THOMAS, R., 1958. Le genres Difflugia, Pentagonia, Maghrebia et Hoogenraadia (Rhizopodes Testacès) en Afrique. Archiv für Protistenkunde, vol. 103, p. 1-370.

-, 1960. Le genre Cucurbitella Pènard. Archiv für Protistenkunde, vol. 104, p. 569-602.

GOLEMANSKY, V. and TODOROV, M., 2004. Shell morphology, biometry and distribution of some marine interstitial testate amoebae (Sarcodina: Rhizopoda). Acta Protozoologica, vol. 43, p. 147-162.
GREEN, J., 1994. The temperate tropical gradient of planktonic Protozoa and Rotifera. Hydrobiologia, vol. 272, p. 13-26. http:// dx.doi.org/10.1007/BF00006509

LANSAC-TÔHA, FA., ALVES, GM., VELHO, LFM., ROBERTSON, BA. and JOKO, CY., 2008. Composition and occurrence of testate amoebae in the Curuá-Una Reservoir (State of Pará, Brazil). Acta Limnologica Brasiliensia, vol. 20, p. 177-195.

LANSAC-TÔHA, FA., BONECKER, CC. and VELHO, LFM., 2004. Composition, species richness and abundance of the zooplankton community. In THOMAZ, S.M., AGOSTINHO, A.A. and HAHN, NS. (Eds.). The Upper Paraná River and its floodplain: physical aspects, ecology and conservation. Leiden: Backhuys Publishers. p. 145-190.

LANSAC-TÔHA, FA., BONECKER, CC., VELHO, LFM., SIMÕES, NR., DIAS, JD., ALVES, GM. and TAKAHASHI, EM., 2009. Biodiversity of zooplankton communities in the Upper Paraná River floodplain: interannual variation from long-term studies. Brazilian Journal of Biology, vol. 69, p. 539-549. PMid:19738961. http://dx.doi.org/10.1590/S1519-69842009000300009

LANSAC-TÔHA, FA., VELHO, L F.M. and BONECKER, C.C., 2003. Influência de macrófitas aquáticas sobre a estrutura da comunidade zooplanctônica. In THOMAZ, S.M. and BINI, LM. (Eds.). Ecologia e manejo de macrófitas aquáticas. Maringá: Eduem. p. 231-242.

LANSAC-TÔHA, FA., VELHO, LFM., CALLEGARI, M C.Z. and BONECKER, C.C., 2000. On the occurrence of testate amoebae (Rhizopodea - Sarcodina) in brazilian inland waters. I Family Arcellidae. Acta Scientiarum, vol. 22, p. 355-363.

LANSAC-TÔHA, FA., ZIMMERMANN-CALLEGARI, MC., ALVES, GM., VELHO, L F.M. and FULONE, L.J., 2007. Species richness and geographic distribution of testate amoebae (Rhizopoda) in Brazilian freshwater environments. Acta Scientiarum Biological Sciences, vol. 29, p. 185-195.

LEÃO, CJ., LEIPNITZ, II. and FERREIRA, F., 2009. Levantamento da biodiversidade de amebas testáceas em sedimentos de lagoas artificiais de São Leopoldo, Rio Grande do Sul, Brasil. Bioikos, vol. 23 , p. 39-49.

LEIPNITZ, I., SILVA, JLL., LEÃO, CJ., FERREIRA, F. and HANSEN, MAF., 2006. Amebas testáceas (Protozoa, Rhizopoda) de ambientes límnicos do Parque Nacional da Lagoa do Peixe, RS, Brasil. GAEA, vol. 2, p. 47-58.

MATTHEEUSSEN, R., LEDEGANCK, P., VINCKE, S., VAN DE VIJVER, B., NIJS, I. and BEYENS, L., 2005. Habitat selection of aquatic testate amoebae communities on Qeqertarsuaq (Disko Island), West Greenland. Acta Protozoologica, vol. 44, p. 253-263.

OGDEN, CG. and HEDLEY, RH., 1980. An atlas of freshwater testate amoebae. Oxford: University Press. 222 p.

OKSANEN, J., BLANCHET, FG., KINDT, R., LEGENDRE, P., O'HARA, B., SIMPSON, GL., SOLYMOS, P., STEVENS, M H.H. and WAGNER, H., 2010. Vegan: Community ecology package. R package version 1.17-3.

R DEVELOPMENT CORE TEAM (2011) R: A Language and Environment for Statistical Computing. Vienna: R Foundation for Statistical Computing. Available from: <http://www.R-project.org/>.

SCHÖNBORN, W., 1962. Über planktismus und ziklomorphose bei Difflugia limnetica (Levander) Pénard. Limnologica, vol. 1, p. 21-34. 
SMITH, HG., BOBROV, A. and LARA, E., 2008. Diversity and biogeography of testate amoebae. Biodiversity and Conservation, vol. 17, p. 329-343. http://dx.doi.org/10.1007/s10531-007-9260-9

SNEGOVAYA, N. and ALEKPEROV, I., 2009. New testate amoebae (Protozoa, Testacea) from the Northern-East Azerbaijan inland water bodies. Protistology, vol. 6, p. 111-125.

SOUZA, MBG., 2008. Guia das tecamebas. Bacia do rio Peruaçu - Minas Gerais. Subsídio para conservação e monitoramento da Bacia do Rio São Francisco. Belo Horizonte: Editora UFMG. 159 p.

ŠTĚPÁNEK, M. and JIŘÍ, J., 1958. Difflugia gramen Pénard, Difflugia gramen var. achlora Pénard and Difflugia gramen $\mathrm{f}$. globulosa f. n. Hydrobiologia, vol. 10, p. 138-156. http://dx.doi. org/10.1007/BF00142184

TEIXEIRA, MC., SANTANA, NF., AZEVEDO, J C.R. and PAGIORO, T.A., 2008. Padrões de variação do carbono orgânico na planície de inundação do alto rio Paraná. Oecologia Brasiliensis, vol. 12, p. 57-65.

THOMAZ, SM., DIBBLE, ED., EVANGELISTA, LR., HIGUTI, J. and BINI, LM., 2008. Influence of aquatic macrophyte habitat complexity on invertebrate abundance and richness in tropical lagoons. Freshwater Biology, vol. 53, p. 358-367.

TODOROV, M., GOLEMANSKY, V. and BLAGOVEST, T., 2008. Diversity and biotopic distribution of testate amoebae (Protozoa : Arcellinida and Euglyphida) in the Batak Reservoir (Southern Bulgaria). Acta Zoologica Bulgarica, vol. 60, p. 115-124.
VELHO, LFM., BINI, LM. and LANSAC-TÔHA, FA., 2004. Testate amoebae (Rhizopoda) diversity in plankton of the upper Paraná river floodplain, Brazil. Hydrobiologia, vol. 523, p. 103 111. http://dx.doi.org/10.1023/B:HYDR.0000033098.46753.9f

VELHO, L F.M. and LANSAC-TÔHA, F.A., 1996. Testate amoebae (Rhizopodea-Sarcodina) from zooplankton of the high Paraná river floodplain, State of Mato Grosso do Sul, Brazil: II Family Difflugidae. Studies on Neotropical Fauna and Environment, vol. 31, p. 179-192. http://dx.doi.org/10.1076/snfe.31.3.179.13342

VELHO, LFM., LANSAC-TÔHA, FA. and BINI, LM., 2003. Influence of environmental heterogeneity on the structure of testate amoebae (Protozoa, Rhizopoda) assemblages in the plankton of the upper Paraná River floodplain, Brazil. International Review of Hydrobiology, vol. 88, p. 154-166. http://dx.doi.org/10.1002/ iroh.200390011

VELHO, LFM., LANSAC-TÔHA, FA. and SERAFIM-JUNIOR, M., 1996. Testate amoebae (Rhizopodea - Sarcodina) from zooplankton of the high Paraná river floodplain, State of Mato Grosso do Sul, Brazil: I Families Arcellidae and Centropyxidae. Studies on Neotropical Fauna and Environment, vol. 31, p. 35-50. http://dx.doi.org/10.1076/snfe.31.1.35.13315

VUCETICH, MC., 1973. Estudio de tecamebianos argentinos, en especial los del dominio pampasico. Revista del Museo de La Plata, vol. 11, p. 287-332. 